Jurnal

\title{
Stratifikasi Risiko, Cost-Analysis dan Jaminan Kesehatan Nasional di Bidang Kardiovaskular
}

\author{
Suko Adiarto
}

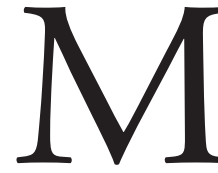

ulai berlakunya sistem kesehatan nasional di Indonesia menandai era baru di bidang pembiayaan kesehatan nasional, dimana pembiayaan kesehatan yang sebelumnya didominasi oleh pembayaran tunai secara pribadi kini secara perlahan tapi pasti telah bergeser pada sistem asuransi, dimana keikutsertaan seluruh warga negara merupakan salah kunci sukses terselenggaranya sistem pembiayaan ini dengan baik. Berkaca pada pendapat para ahli di bidang pembiayaan kesehatan dan pengalaman negara-negara maju, tidak disangsikan lagi, ketika telah berjalan dengan sempurna sistem ini merupakan sistem pembiayaan terbaik. Tentu saja pada tahap awal pelaksanaan sistem jaminan ini masih terdapat beberapa kekurangan mendasar yang perlu mendapat perhatian serius untuk dapat segera diperbaiki.

Seperti mengkonfirmasi data statistik yang telah ada tentang mortalitas dan morbiditas, BPJS kesehatan baru-baru ini me release data penyakit dengan pembiayaan kesehatan tertinggi dimana penyakit jantung dan pembuluh darah, keganasan (kanker) dan penyakit ginjal kronik merupakan 3 penyakit yang memuncaki tabel pengeluaran keuangan BPJS kesehatan. ${ }^{1}$ Penyakit jantung dan pembuluh darah berada di urutan pertama dengan jumlah pengeluaran

\footnotetext{
Alamat Korespondensi

Dr. Suko Adiarto. Divisi Aritmia, Department of Cardiology and Vascular Medicine, Faculty of Medicine Universitas Indonesia National Cardiovasular Center Harapan Kita, Jakarta, Indonesia. . E-mail: sukoadiarto@gmail.com
}

jauh melebihi urutan kedua dan ketiga. Hal ini tentu saja perlu mendapat perhatian yang sangat serius dari kita semua sebagai praktisi di bidang Kardiovaskular. Data ini menunjukkan bahwa pencegahan terhadap penyakit jantung dan pembuluh darah harus menjadi prioritas

Gerakan pencegahan primer penyakit jantung dan pembuluh darah harus lebih banyak diperankan oleh semua pihak, namun demikian langkah yang efektif akan sangat bermanfaat bila dilakukan oleh pemerintah sebagai pelaksana dan pengambil kebijakan kesehatan. Langkah-langkah seperti penyuluhan dengan iklan layanan masyarakat untuk mengenali faktor-faktor risiko kardiovaskular, pembatasan akses terhadap rokok peningkatan cukai, pembatasan usia merokok, pembatasan kadar garam dalam makanan kemasan telah diterapkan pada beberapa negara maju dan diketahui berhasil menurunkan mortalitas dan morbiditas penyakit kardiovaskular. ${ }^{2}$ Penerapannya di Indonesia secara lebih komprehensif tentu akan memberikan dampak yang signifikan.

Sayangnya, walaupun terbukti efektif, langkahlangkah pencegahan primer tersebut baru akan memberikan dampak yang signifikan dalam waktu yang tidak singkat. Sementara gelombang pasien penyakit kardiovaskular terus menyerbu berbagai fasilitas kesehatan, dengan tingkat rujukan untuk tindakan invasif maupun operatif yang cukup tinggi sehingga menimbulkan daftar antrian yang cukup panjang pada pusat-pusat kesehatan kardiovaskular utama. Pengobatan yang agresif, tindakan invasif dan operatif inilah yang ditengarai menjadi sebab tingginya 
pembiayaan kesehatan di bidang kardiovaskular. Apakah strategi ini memang diperlukan? dan apakah sebanding dengan besarnya pembiayaan kesehatan yang dikeluarkan?

Untuk menjawab pertanyaan di atas tentu diperlukan data yang akurat tidak hanya dari jumlah pembiayaan yang dikeluarkan, tetapi juga parameterparameter lain, seperti jumlah komplikasi, readmisi dan kejadian kardiovaskular mayor dihindarkan, number needed to treat to save one life (NNT), hilangnya produktivitas kerja akibat penyakit/cacat permanen/ meninggal. Dari sisi klinisi, indikasi terhadap pengobatan, tindakan diagnostik/intervensi maupun pembedahan perlu ditingkatkan penerapannya berdasarkan evidence based (pengobatan berbasis bukti), sehingga pengobatan/prosedur yang diterapkan tidak hanya sesuai indikasi dan stratifikasi risiko, tetapi juga diketahui akan bermanfaat dalam menurunkan mortalitas dan morbiditas. Beberapa contoh pengobatan yang masih menjadi perdebatan antara klinisi dan penjamin biaya kesehatan diantaranya:

- Penggunaan high intensity statin untuk prevensi primer dan sekunder ${ }^{3}$

- Pemberian ARB (Angiotensin Receptor Antagonist) dosis maksimal pada gagal jantung kronik ${ }^{4}$

- Revaskularisasi secara rutin Vs. Revaskularisasi hanya untuk kelompok risiko tinggi pada Angina Pektoris Stabil ${ }^{5}$

- Pencegahan primer kematian jantung mendadak pada penderita dengan Fraksi ejeksi rendah dengan Intra Cardiac Defibrilator (ICD) ${ }^{6}$

- Thaoracic Endovascular Aortic Repair/ Endovascular aortic Repair pada aneurisma dan diseksi aorta ${ }^{7}$

- Penggunaan LAA closure untuk pencegahan tromboemboli pada Fibrilasi atrium ${ }^{8}$

Semua contoh diatas telah dikaji efektivitasnya dalam penelitian skala besar di negara-negara maju. Penerapannya di Indonesia masih belum mendapat penjaminan karena cost yang dikeluarkan akan sangat besar mengingat tingginya teknologi yang digunakan dan besarnya populasi pasien yang sesungguhnya eligible untuk pengobatan/prosedur di atas. Namun demikian, ketika manfaat (benefit) yang diperoleh juga diperhitungkan dalam jangka panjang, niscaya manfaatnya akan sangat terasa.

Bagi penjamin biaya kesehatan pada umurnya yang masih sangat belia, tentu saat ini masih berkonsentrasi pada pengendalian biaya yang dikeluarkan hari ini dan belum banyak mempunyai data tentang manfaat yang diperoleh di masa datang. Sebuah proses alamiah yang sangat wajar, namun tentu kita sebagai praktisi berharap agar masa ini segera dilalui, sehingga pengobatan dan prosedur yang bermanfaat dapat segera mendapatkan jaminan. Manfaat yang terasa tidak saja bagi peserta (pasien) tetapi juga untuk pengurangan biaya kesehatan itu sendiri, karena dapat dipastikan ketika dilakukan pada indikasi dan stratifikasi risiko yang tepat pengobatan/prosedur medis akan menurunkan angka kematian/angka perawatan/komplikasi dan hilangnya produktivitas di masa depan

\section{Daftar Pustaka}

1. Daftar 10 Penyakit Terbanyak yang Dikeluhkan Peserta BPJS. 2014. (Accessed 28 March, 2016, at http://health.liputan6.com/ $\mathrm{read} / 832600 /$ daftar-10-penyakit-terbanyak-yang-dikeluhkanpeserta-bpjs.)

2. Weintraub WS, Daniels SR, Burke LE, Franklin BA, Goff DC, Jr., Hayman LL, et al. Value of primordial and primary prevention for cardiovascular disease: a policy statement from the American Heart Association. Circulation 2011;124:967-90.

3. Cannon CP, Steinberg BA, Murphy SA, Mega JL, Braunwald E. Meta-analysis of cardiovascular outcomes trials comparing intensive versus moderate statin therapy. J Am Coll Cardiol 2006;48:438-45.

4. McDonagh T. ARBs in chronic heart failure. Br J Cardiol 2010;17:s10-s2.

5. Pursnani S, Korley F, Gopaul R, Kanade P, Chandra N, Shaw $\mathrm{RE}$, et al. Percutaneous coronary intervention versus optimal medical therapy in stable coronary artery disease: a systematic review and meta-analysis of randomized clinical trials. Circ Cardiovasc Interv 2012;5:476-90.

6. Schoenfeld MH. Contemporary pacemaker and defibrillator device therapy: challenges confronting the general cardiologist. Circulation 2007;115:638-53.

7. Erbel R, Aboyans V, Boileau C, Bossone E, Bartolomeo RD, Eggebrecht H, et al. 2014 ESC Guidelines on the diagnosis and treatment of aortic diseases: Document covering acute and chronic aortic diseases of the thoracic and abdominal aorta of the adult. The Task Force for the Diagnosis and Treatment of Aortic Diseases of the European Society of Cardiology (ESC). Eur Heart J 2014;35:2873-926.

8. De Backer O, Arnous S, Ihlemann N, Vejlstrup N, Jorgensen E, Pehrson S, et al. Percutaneous left atrial appendage occlusion for stroke prevention in atrial fibrillation: an update. Open Heart 2014;1:e000020. 